\title{
Inductively Coupled Plasma Atomic Emission Spectrometric Determination of Indium (In) and Gallium (Ga) in Thorium Matrix After Chemical Separation Using Cyanex 923 Extractant
}

\author{
V.C. Adya, Mithlesh Kumar, Arijit Sengupta*, and V. Natarajan \\ Radiochemistry Division, Bhabha Atomic Research Centre, Trombay, Mumbai 400085, India
}

\section{INTRODUCTION}

Quality assurance of nuclear fuel materials such as thorium (Th), plutonium $(\mathrm{Pu})$, and uranium $(\mathrm{U})$ is essential prior to their introduction into the reactor. The chemical purity and characterization of major and minor constituents defines the chemical quality control of the fuel. Trace metallic constituents affect the neutron economy, fuel density, and fuel fabrication process. Spectroscopic methods are most often used for trace metal characterization of fuel materials (1-5) such as inductively coupled plasma atomic emission spectrometry (ICP-AES) because of its simplicity and simultaneous multi-element capability coupled with high sensitivity, analytical range, and good precision (613). Gallium (Ga) is used as a heat exchanger in nuclear reactors. An alloy of indium (In), silver (Ag), and cadmium (Cd) has been used in nuclear control rods. Indium is one of the specification elements in nuclear fuel because of its high neutron absorption cross section (194 barns). Thus, in view of the importance of Ga and In in the nuclear industry, it becomes imperative to determine these elements in nuclear fuels and fuel materials. The determination of Ga and In in uranium and plutonium by inductively coupled plasma atomic emission spectrometry (ICP-AES) and graphite furnace atomic absorption spectrometry (GF-AAS) has been reported earlier by us $(14,15)$. The assay of metallic elements in refractory matrices like thorium oxide

*Corresponding author.

E-mail: arijita@barc.gov.in

\section{ABSTRACT}

A methodology was developed involving a solvent extraction technique using 30\% Cyanex 923 extractant in dodecane for the quantitative separation of thorium followed by the determination of indium (In) and gallium (Ga) at trace levels by inductively coupled plasma atomic emission spectrometry (ICP-AES). The analytical performance of the different analytical lines of $\mathrm{Ga}$ and In and the spectral interference study revealed that $\mathrm{Ga}$ at the 250.000-nm and 287.424-nm lines and In at the 203.606-nm line are suitable for their determination in a Th matrix. The quantitative recovery of both elements in the separated samples was confirmed from radiometric studies. The method was validated using synthetic samples.

$\left(\mathrm{ThO}_{2}\right)$, plutonium oxide $\left(\mathrm{PuO}_{2}\right)$, and uranium oxide $\left(\mathrm{U}_{3} \mathrm{O}_{8}\right)$ with rich emission spectra requires quantitative separation of the major matrix from that of the analytes to avoid spectral interference from the emission-rich matrices to meet specification limits laid down by fuel designers (16-22). For analytical purposes, separation procedures should be able to separate the major matrix by a factor of $10^{4}$ to $10^{5}$ without loss of the analytes present at the $\mu \mathrm{g} / \mathrm{mL}$ concentration levels. This requires that established chemical separation procedures be regularly re-evaluated for their analytical purposes. Methods have been developed in our laboratory for determining common impurities and rare earths in complex matrices such as $\mathrm{Pu}, \mathrm{U}$, and Th using the different extractants of Tri-n-octyl amine and Cyanex ${ }^{\circledR} 923(23,24)$. In this paper, a solvent extraction procedure has been successfully employed to separate $\mathrm{Ga}$ and In from Th and their subsequent determination by ICP-AES/radiometric technique. It is well known from earlier studies on U/Pu matrices that extraction properties are better for Cyanex 923 as compared to tri-n-butyl phosphate (TBP), a well-known extractant for $\mathrm{U} / \mathrm{Pu}$ in the nuclear industry (25).

\section{EXPERIMENTAL}

\section{ICP-AES Analysis}

In this study, a Jobin Yvon Panorama high-resolution ICP-AES was used, having a $40.68 \mathrm{MHz}$ operating radio frequency, forward power of $1 \mathrm{KW}$, reflected power of $<10 \mathrm{~W}$, and a radial viewing plasma. The plasma gas flow was $12 \mathrm{~L} / \mathrm{min}$, while the cooling gas flow and sample gas flow rates were 0.2 and $0.85 \mathrm{~L} / \mathrm{min}$, respectively. The optimized experimental parameters are summarized in Table I.

\section{Standards and Reagents}

The standard solutions for all of the elements were prepared from CertiPUR ${ }^{\circledR}$ ICP multi-standard solutions (E-Merck, Darmstadt, Germany) by proper dilution. Suprapur ${ }^{\circledR} \mathrm{HNO}_{3}$ (E-Merck, Darmstadt, Germany) and quartz doubly distilled Milli-Q ${ }^{\circledR}$ water (Millipore Corporation, USA) were used throughout this study. Multi-point standardization was carried out using $0.5 \mathrm{M} \mathrm{HNO}_{3}$ as a blank and $0.05-1000 \mu \mathrm{g} / \mathrm{L}$ of the correspond- 
ing elemental standard in $0.5 \mathrm{M}$ $\mathrm{HNO}_{3}$ as the higher calibration standard for each emission line after proper peak search.

\section{Preparation of Standards and Samples}

Stock solutions of $\mathrm{Ga}$ and In at $10 \mathrm{mg} / \mathrm{mL}$ were prepared by dissolving SpecPure ${ }^{\circledR}$ (JohnsonMatthey Chemicals, Ltd., U.K.) oxides of the individual elements in concentrated $\mathrm{HNO}_{3}$. High purity nitric acid (E-Merck) and quartz double-distilled water were used to dilute the standards in $1 \mathrm{M} \mathrm{HNO}_{3}$ for all ICP-AES studies. Standards containing $\mathrm{Ga}$ and $\mathrm{In}$ in the concentration range of 1 to $100 \mu \mathrm{g} / \mathrm{mL}$ and 0.5 to $50 \mu \mathrm{g} / \mathrm{mL}$, respectively, were prepared by appropriate dilution of $1 \mathrm{mg} / \mathrm{mL}$ solution of In and $\mathrm{Ga}$. Standards of Th in the range of $1-100 \mu \mathrm{g} / \mathrm{mL}$ were also prepared in $1 \mathrm{M} \mathrm{HNO}_{3}$. Cyanex 923 (American Cyanamid Company, USA) was appropriately diluted using dodecane (AnalR ${ }^{\circledR}$ grade, BDH, Pooly, England) as the diluent. Radiotracers of In $\left({ }^{114 m} \operatorname{In}^{*}, t_{0.5}=49.5 d\right)$ and

\section{TABLE I}

Instrumental Operating Parameters for ICP-AES

\begin{tabular}{lr}
\hline Spectrometer: & \multicolumn{2}{c}{ Model 1M JY50P } \\
Panorama ICP-AES
\end{tabular}

$\mathrm{Ga}\left({ }^{72} \mathrm{Ga}\right)$ were procured from the Board of Radiation \& Isotope Technology, India (BRIT), the Department of Atomic Energy (DAE), India (Institute funded by the Government of India, mostly dedicated to isotope production).

\section{Preparation of Certified Refer- ence Material and Synthetic Samples}

The certified reference material $\mathrm{ThO}_{2}$ (certified during inter-laboratory comparison experiments by different Laboratories of the Department of Atomic Energy, India) was dissolved in concentrated $\mathrm{HNO}_{3}+0.05 \mathrm{M} \mathrm{HF}$ acid mixture, made up to $25 \mathrm{~mL}$ in $4 \mathrm{M} \mathrm{HNO}_{3}$, and then varying amounts of $\mathrm{Ga}$ and In were added. Experiments were conducted with three synthetic samples [prepared inhouse by addition of different concentrations (ppm range) of $\mathrm{Ga}$ and In in the certified reference material $\mathrm{ThO}_{2}$ as indicated above] at different concentration levels of $\mathrm{Ga}$ and In. Of the three samples studied, two were based on $500 \mathrm{mg}$ of Th and one sample was based on $100 \mathrm{mg}$ of Th. A 100-mg sample was chosen to estimate the analytes at the \% levels after proper dilution. A solvent extraction procedure using 30\% Cyanex 923/dodecane/ $4 \mathrm{M} \mathrm{HNO}_{3}$ was employed to separate $\mathrm{Th}$, with $\mathrm{Ga}$ and In remaining in the aqueous phase. The aqueous phase after extraction was made up to $10 \mathrm{~mL}$ in $1 \mathrm{M} \mathrm{HNO}_{3}$ for ICP-AES analysis.

The extractant mixture of $30 \%$ Cyanex 923 in dodecane was allowed to equilibrate with the aqueous phase containing $500 \mathrm{mg}$ Th samples with a phase ratio of 1:1. After the organic phase was separated, the extractant mixture was also added to the aqueous phase. For the quantitative separa-

\section{* $114 m$ In}

The ' $m$ ' = meta stable state of indium having an atomic mass of 114. tion of Th, this extractant was required to be added four times. Finally, the aqueous phase was allowed to equilibrate with only dodecane to separate traces of Cyanex 923 locked in the aqueous phase. Finally, for a 100-mg Th sample, two separate additions of Cyanex 923 in dodecane were required, followed by the application of dodecane alone for the quantitative separation of Th without loss of the analytes (Ga, In) in the aqueous phase.

\section{Tracer Studies}

For tracer studies, a known amount of individual ${ }^{114 \mathrm{~m}} \mathrm{In}$ and ${ }^{72} \mathrm{Ga}$ activity was added to $100 \mathrm{mg}$ of Th in $4 \mathrm{M} \mathrm{HNO}_{3}$. The activity due to In and Ga was monitored before and after the extraction of $\mathrm{Th}$. The samples were counted for $300 \mathrm{sec}-$ onds on the HPGe detector ( $40 \%$ relative efficiency), which has an energy resolution of $2 \mathrm{keV}$ at 1333 $\mathrm{keV}$ of ${ }^{60} \mathrm{Co}$. The data were acquired on the 8K MCA detector. Because of better resolution, the $\mathrm{HpGe}$ detector was chosen to avoid interference from other isotopes. Samples and standards of the same geometry were kept at the same distance from the detector for the counting, so that the efficiency of the HPGe detector remained the same for the samples and the standards. They were counted for a sufficient length of time (60 minutes) to minimize error in counting. In radiometry, the error can be expressed as $1 / \sqrt{ } \mathrm{N}$ (where $\mathrm{N}$ is the total number of counts). Counting the samples for a longer period of time gave more number of counts for a particular peak and hence, less error is associated with the counting.

\section{RESULTS AND DISCUSSION}

The determination of trace elements in Th by ICP-AES requires prior separation of the matrix due to possible spectral interferences (19-20). In this context, the suit- 
ability of Cyanex 923 extraction for the separation of Th from In and $\mathrm{Ga}$ was investigated. Cyanex 923 is expected to be slightly less basic than tri-n-octylphosphine oxide (TOPO) due to replacement of the octyl groups by the hexyl groups. Thus, it will have extraction properties better than those of TBP but less than TOPO with respect to $\mathrm{U} / \mathrm{Pu} / \mathrm{Th}$ matrices. At the same time, it may not extract impurity elements to an appreciable extent as with TOPO. Furthermore, Cyanex 923 has the added advantage that, being a liquid, it is completely miscible with all the com- monly used hydrocarbon diluents.

\section{Determination of Ga and In in Th Matrix by ICP-AES}

Individual solutions of $\mathrm{Ga}$ and In $(100 \mu \mathrm{g} / \mathrm{mL})$ were introduced into the ICP. The parameters were suitably optimized to select analytical spectral lines free from the normal interfering elements. Investigations on the spectral interference of thorium on the In and $\mathrm{Ga}$ analytical channels and using high purity Th revealed that up to $20 \mu \mathrm{g} / \mathrm{mL}$ of $\mathrm{Th}$ there is no significant contribution for the analytes. It was also observed that the In $203.606 \mathrm{~nm}$ and the $\mathrm{Ga}$ $250.000 \mathrm{~nm}$ and $287.424 \mathrm{~nm}$ analytical lines were the most suitable lines for trace determination of In and $\mathrm{Ga}$ in a thorium matrix on the basis of spectral interference and analytical performance (Figure 1).

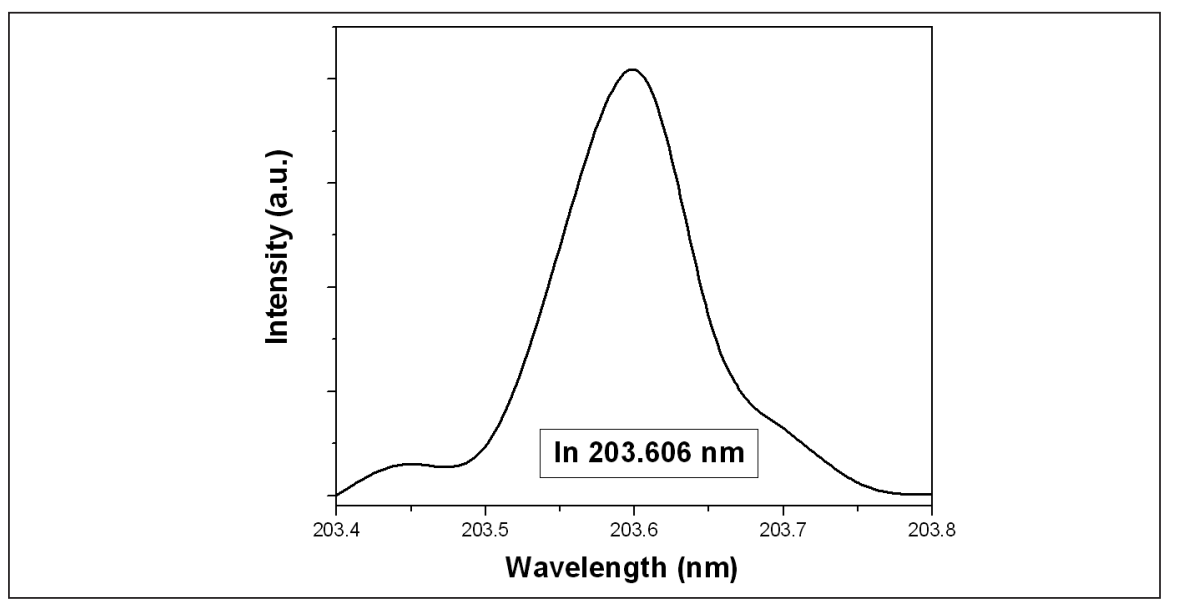

\section{Atomic Apectroscopy \\ 1 Vol. 36(6), Nov./Dec. 2015}

The analytical performance of the synthetic samples demonstrated the successful application of the ICP-AES-based procedure for the determination of Ga and In and the results are tabulated in Tables II and III, respectively.

\section{Optimization of Separation Procedure}

Quantitative chemical separation of Th was carried out using five contacts of 30\% Cyanex 923 extractant in dodecane with the phase ratio of $1: 1$. The initial Th concentration was $\sim 150 \mathrm{mg} / \mathrm{mL}$. The concentration of Th after each contact was determined by ICP-AES using the Th 283.720-nm line. Table IV summarizes the concentration of Th after each contact. The proposed methodology for the separation of Th without loss of Ga and In, even at trace levels, was confirmed by using ${ }^{114 \mathrm{~m}} \mathrm{In}$ and ${ }^{72} \mathrm{Ga}$ tracers at the $191.6 \mathrm{keV}$ of ${ }^{114 m} \mathrm{In}$ and $834.0 \mathrm{keV}$ of ${ }^{72} \mathrm{Ga}$ gamma line . The (\%) recovery was found to be within $95-105 \%$ and the analytical results obtained are listed in Table V.

\section{Validation of the Methodology Using Synthetic Samples}

Chemical separation of Th, followed by the analysis of the raffinate, was adopted for the present studies and the optimized method
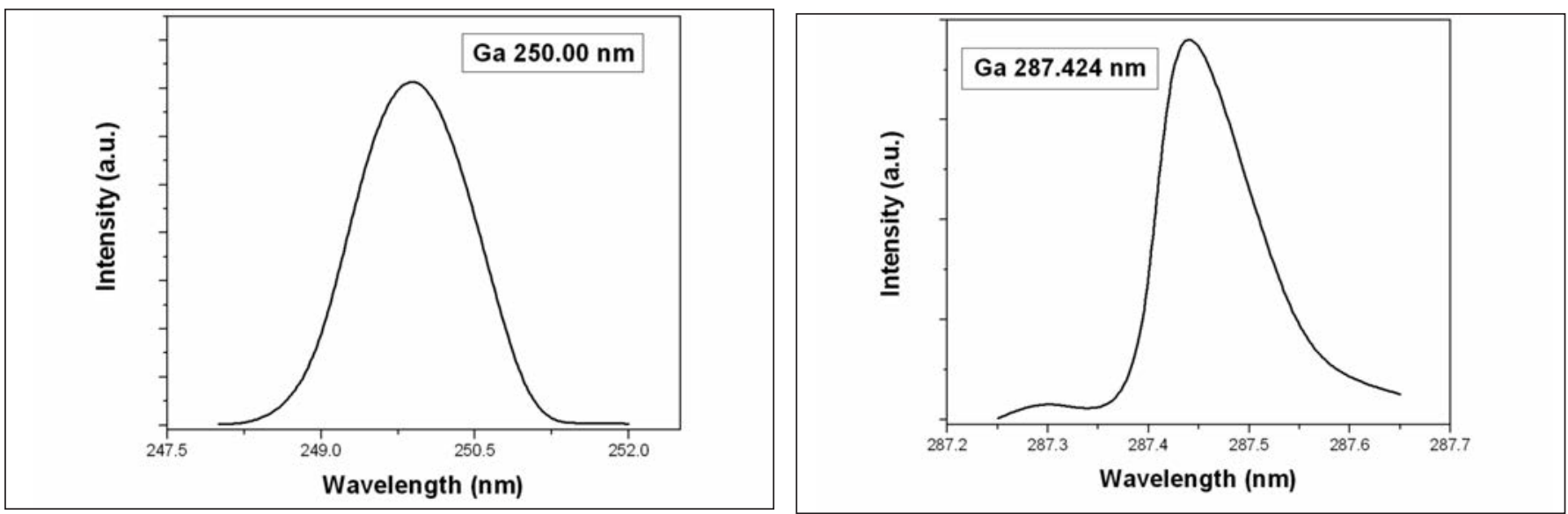

Fig. 1. Emission profiles for In $203.606 \mathrm{~nm}$, Ga $250.00 \mathrm{~nm}$, and Ga $287.424 \mathrm{~nm}$. 
TABLE II

Determination of In by ICP-AES Using Different Analytical Wavelengths

\begin{tabular}{|c|c|c|c|c|}
\hline $\begin{array}{l}\text { In } \\
(\mathrm{mg} / \mathrm{L})\end{array}$ & $\begin{array}{c}203.606 \mathrm{~nm} \\
\quad(\mathrm{mg} / \mathrm{L})\end{array}$ & $\begin{array}{c}303.609 \mathrm{~nm} \\
(\mathrm{mg} / \mathrm{L})\end{array}$ & $\begin{array}{c}325.609 \mathrm{~nm} \\
(\mathrm{mg} / \mathrm{L})\end{array}$ & $\begin{array}{l}451.131 \mathrm{~nm} \\
(\mathrm{mg} / \mathrm{L})\end{array}$ \\
\hline 1 & $0.90 \pm 0.02$ & $0.98 \pm 0.02$ & $0.93 \pm 0.07$ & $0.90 \pm 0.04$ \\
\hline 10 & $9.8 \pm 0.8$ & $10.2 \pm 0.6$ & $9.7 \pm 0.4$ & $9.9 \pm 0.5$ \\
\hline 100 & $98.5 \pm 2.5$ & $97 \pm 4$ & $100.3 \pm 1.6$ & $101.6 \pm 1.5$ \\
\hline 1000 & $1000 \pm 3$ & $992 \pm 9$ & $995 \pm 6$ & $1001 \pm 6$ \\
\hline D.L. $(\mathrm{mg} / \mathrm{L})$ & 0.21 & 0.33 & 0.07 & 50 \\
\hline $\begin{array}{l}\text { Sensitivity } \\
(\text { counts } / \mathrm{mg} / \mathrm{L})\end{array}$ & 527 & 390 & $1.2 \times 10^{3}$ & 10.5 \\
\hline $\begin{array}{c}\text { Linear Dynamic } \\
\text { Range }(\mathrm{mg} / \mathrm{L})\end{array}$ & $0.21-1000$ & $0.33-700$ & $0.07-800$ & $10.5-500$ \\
\hline (\%) RSD & $\sim 2 \%$ & $\sim 2 \%$ & $\sim 3 \%$ & $\sim 5 \%$ \\
\hline $\begin{array}{l}\text { Tolerance of Th } \\
\text { (mg/L) }\end{array}$ & 5 & 50 & 100 & 100 \\
\hline
\end{tabular}

TABLE III

Determination of Ga by ICP-AES

Using Different Analytical Wavelengths

\begin{tabular}{lccc}
\hline Ga $(\mathrm{mg} / \mathrm{L})$ & $\begin{array}{c}250.000 \mathrm{~nm} \\
(\mathrm{mg} / \mathrm{L})\end{array}$ & $\begin{array}{c}287.424 \mathrm{~nm} \\
(\mathrm{mg} / \mathrm{L})\end{array}$ & $\begin{array}{c}417.206 \mathrm{~nm} \\
(\mathrm{mg} / \mathrm{L})\end{array}$ \\
\hline 1 & $0.90 \pm 0.02$ & $0.98 \pm 0.02$ & $0.93 \pm 0.07$ \\
10 & $9.8 \pm 0.8$ & $10.2 \pm 0.6$ & $9.7 \pm 0.4$ \\
100 & $98.5 \pm 2.5$ & $97 \pm 4$ & $100.3 \pm 1.6$ \\
1000 & $1000 \pm 3$ & $992 \pm 9$ & $995 \pm 6$ \\
$\begin{array}{l}\text { D.L. }(\mathrm{mg} / \mathrm{L}) \\
\text { Sensitivity } \\
\quad(\text { counts/mg/L) }\end{array}$ & 0.07 & 0.30 & 0.1 \\
$\begin{array}{c}\text { Linear Dynamic } \\
\text { Range }(\mathrm{mg} / \mathrm{L})\end{array}$ & $0.07-1000$ & $0.30-1000$ & $0.1-1000$ \\
$\begin{array}{c}(\%) \text { RSD } \\
\text { Tolerance of Th } \\
(\mathrm{mg} / \mathrm{L})\end{array}$ & $\sim 2 \%$ & $\sim 3 \%$ & $\sim 3 \%$ \\
\hline
\end{tabular}

TABLE V

Extraction Studies Of Ga and In Using Radiotracers

\begin{tabular}{|c|c|c|c|c|}
\hline Elemen & $\begin{array}{l}\mathrm{t} \text { Gamma } \\
\text { Energy (keV) }\end{array}$ & $\begin{array}{l}\text { Counts Before } \\
\text { Extraction }\end{array}$ & $\begin{array}{c}\text { Counts After } \\
\text { Five Extractions }\end{array}$ & $\begin{array}{c}(\%) \\
\text { Recovery }\end{array}$ \\
\hline In & 191.6 & 19,194 & 19,633 & 102.2 \\
\hline $\mathrm{Ga}$ & 834.0 & 56,783 & $5,455,096$ & 96.1 \\
\hline
\end{tabular}

TABLE IV

Amount of Th in Aqueous Phase After Each Contact With Cyanex 301

\begin{tabular}{cr}
\hline No. of Contacts & $\begin{array}{c}\text { Th Conc. in } \\
\text { Aqueous Phase }\end{array}$ \\
\hline Initial & $150 \mathrm{mg} / \mathrm{mL}$ \\
1 & $94 \mathrm{mg} / \mathrm{mL}$ \\
2 & $4 \mathrm{mg} / \mathrm{mL}$ \\
3 & $200 \mu \mathrm{g} / \mathrm{mL}$ \\
4 & $11 \mu \mathrm{g} / \mathrm{mL}$ \\
5 & $0.3 \mu \mathrm{g} / \mathrm{mL}$ \\
\hline
\end{tabular}

was validated using synthetic samples. The concentration of residual Th in all of the samples after five separate applications of $30 \%$ Cyanex 923/dodecane was found to be well below the tolerance limits as specified earlier. The initial Th concentration was $150 \mathrm{mg} / \mathrm{mL}$ to which known amounts of $\mathrm{Ga}$ and In were added. After extraction, the raffinates were analyzed for $\mathrm{Ga}$ and In concentration and the results were found to be satisfactory (as can be seen in Table VI).

\section{CONCLUSION}

A solvent extraction method using 30\% Cyanex 923/dodecae/4M $\mathrm{HNO}_{3}$ has been employed to separate Th from $\mathrm{Ga}$ and In, followed by their determination using inductively coupled plasma atomic emission spectrometry (ICP-AES). Tracer studies have been used to confirm the recovery of In in the separated samples. The concentration of residual Th in the separated samples was found to be less than the tolerance limits (no spectral interference from the Th matrix on Ga and In). The method is useful for the determination of $\mathrm{Ga}$ and $\mathrm{In}$ in a large concentration range using $\mathrm{mg}$ (milligram) to g (gram) samples of thorium. The method was validated using synthetic samples.

$\overline{\text { Received March 10, } 2015 .}$ 


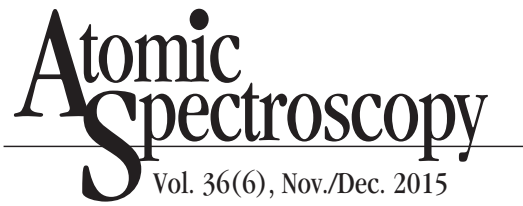

TABLE VI

Analysis of Synthetic Samples for Ga and In

\begin{tabular}{c|cc|ccc}
\hline Sample & \multicolumn{2}{|c|}{ Amount Added $(\mu \mathrm{g} / \mathrm{g})$} & \multicolumn{3}{c}{ Amount Estimated $(\mu \mathrm{g} / \mathrm{g})$} \\
\hline & Ga & In & Ga 250.000 nm & Ga 287.424 nm & In 203.606 nm \\
\hline S-1 & 6.0 & 1.5 & $6.3 \pm 0.31$ & $6.6 \pm 0.21$ & $1.6 \pm 0.12$ \\
S-2 & 15 & 5.0 & $15.2 \pm 0.1$ & $15.5 \pm 0.21$ & $5.3 \pm 0.15$ \\
S-3 & 30 & 10.00 & $30.6 \pm 0.25$ & $32.1 \pm 022$ & $10.7 \pm 0.07$ \\
S-4 & 1 & 100 & $1.0 \pm 0.2$ & $0.97 \pm 0.1$ & $98 \pm 4$ \\
S-5 & 100 & 1 & $102 \pm 4$ & $101 \pm 3$ & $1.1 \pm 0.2$ \\
S-6 & 0.5 & 0.5 & $0.52 \pm 0.03$ & $0.46 \pm 0.03$ & $0.49 \pm 0.03$ \\
\hline
\end{tabular}

\section{REFERENCES}

1. M. H. Abdallah, J. M. Mermet, and C. Trassy, Anal. Chim. Acta 87, 329 (1976).

2. A. Mazzucotellit, F. De Paz, E. Magi, and R. Frache, Anal. Sci. 8 , 189 (1992).

3. S. Greenfield, I.LL. Jones, and C.T. Berry, Analyst 89, 713 (1964).

4. V.A. Fassel and R.N. Kniseley, Anal. Chem. 46, 1110A (1974).

5. R.H. Wendt and V.A. Fassel, Anal. Chem. 37, 920 (1965).

6. J. P. Robin, Pro. Anal. At. Spectrosc. 5, 79 (1982).

7. V.A. Fassel, Anal. Chem.51,1290A (1979).

8. A. Sengupta, B. Rajeswari, R.M. Kadam, and S.V. Godbole, At. Spectrosc. 33(2), 48 (2012).

9. P.W.J.M. Boumans and J.J.A.M. Vrakking, Spectrochim. Acta B 40, 1085 (1985)

10. P.W.J.M. Boumans, and J.J.A.M. Vrakking, Spectrochim. Acta B 42, 819 (1987).

11. C. Moor, T. Lymberopoulou, and V.J. Dietrich, Mikrochim. Acta 136, 123 (2001).

12. Y. Airan, A. Sengupta, S.K. Thulasidas, and V. Natarajan, At. Spectrosc. 36(1), 30 (2015).

13. Y. Airan, A. Sengupta, S.K. Thulasidas, and V.Natarajan, At. Spectrosc. 36(1), 15 (2015).

14. A. Sengupta, S.K. Thulasidas, and V. Natarajan, J Radioanal. Nucl. Chem. DOI: 10.1007/s10967-0143679-8 (2014).
15. M. Kumar, M. Mohapatra, P.J. Purohit, S.K. Thulasidas, N. Goyal, T.K. Seshagiri, and S.V. Godbole, At. Spectrosc. 31, 97 (2010).

16. T.K. Seshagiri, Y. Babu, M.L. Jayanth Kumar, A.G.I. Dalvi, M.D. Sastry and B.D. Joshi, Talanta 31, 773 (1984)

17. V.C. Adya, A. Sengupta, and S.V. Godbole, At. Spectrosc. 35(1), 25 (2014).

18. A. Sengupta and V.C. Adya, J Radioanal. Nucl. Chem. 299, 2023 (2014).

19. A. Sengupta and V.C.Adya, At. Spectrosc. 34(6), 207 (2013).

20. A. Sengupta, S.K. Thulasidas, and V. Natarajan, At. Spectrosc. 35(5), 213 (2014).

21. A.Sengupta, V. C. Adya, and S. V. Godbole, J Radioanal. Nucl. Chem. 292(3), 1259 (2012).

22. A. Sengupta, V.C. Adya, T.K. Seshagiri, and S.V. Godbole, At. Spectrosc. 34(2), 53 (2013).

23. A. Sengupta, V.C. Adya, Mithlesh Kumar, S.K. Thulasidas, S.V. Godbole, and V.K. Manchanda, At. Spectrosc. 32(2), 49 (2011).

24. M.J. Kulkarni, A.A. Argekar, J.N. Mathur, and A.G. Page, Anal. Chim. Acta 370, 163 (1988).

25. A.A. Argekar, M.J. Kulkarni, J.N. Mathur and A.G. Page, Talanta 56, 591 (2002).

26. V. C. Adya, S. K. Thulasidas, M. Kumar, P. J. Purohit, M. Mohapatra, T. K. Seshagiri, and S. V. Godbole, Radiochim. Acta 99, 1 (2011). 